Boise State University

ScholarWorks

Criminal Justice Faculty Publications and

Presentations

Department of Criminal Justice

5-19-2015

Corrections Reform in Kosovo: A Qualitative Study of Canadian Corrections Advisers' Experiences in a Post-Conflict Environment

Danielle Murdoch

Boise State University 


\title{
Corrections Reform in Kosovo: A Qualitative Study of Canadian Corrections Advisers’ Experiences in a Post-Conflict Environment
}

\author{
Danielle Murdoch \\ Department of Criminal Justice \\ Boise State University
}

\begin{abstract}
This case study of corrections reform in Kosovo contributes to the growing academic literature on corrections reform during peacebuilding missions in post-conflict environments. Fourteen Canadian corrections advisers who were deployed to Kosovo between 1999 and 2006 were interviewed about the dynamics and challenges they experienced abroad. Interview transcripts were coded and analysed using NVivo10. Five key themes emerged from the data: the importance of understanding the local context; the prevalence of corruption; the lack of attention and resources devoted to corrections reform in post-conflict Kosovo; the challenges of providing safe and secure confinement for prisoners detained in facilities staffed by police and military personnel; and, the challenges of working with 'experts' who seemingly lacked expertise and genuine concern for developing local capacities. These themes are summarized followed by a discussion of the limitations of the study, the directions for future research, and the policy and practice implications of the findings.
\end{abstract}

Keywords: corrections reform, post-conflict environments, criminal justice reform, security sector reform, peacebuilding

\section{Introduction}

Since the UN was established in 1945, the agency has engaged in 69 peacekeeping missions, with the majority - 56 of the 69 - taking place since 1988. ${ }^{1}$ External intervention in the affairs of sovereign states stems from concerns about human rights violations that occur during times of conflict. This has led to the increased use of UN Charter Chapter VII, which contains provisions that allow nations to intervene - subject to UN Security Council veto privilege - and infringe upon national sovereignty on the premise that external intervention is carried out to promote international peace and security, or address mass human rights violations within another nation's borders. ${ }^{2}$ The arguments pertaining to global security and safety that have arisen following the terrorist attacks against the United States on 11 September 2001 further support external intervention. ${ }^{3}$ Given the potential impact of terrorist and criminal activities, and conflict displacement on people residing outside of, and often far from, post-conflict environments (PCEs; those that have experienced intra- or inter-state conflict), some argue, 'increasing development in conflict zones is akin to increased security at home'. ${ }^{4}$

Liberal peacebuilding, external intervention that is designed to establish peace and stability by conducting development and reform activities to establish liberal democratic institutions and increase respect for human rights abroad, has been touted as the solution to intra-state conflict in the post-Cold War era. Peacebuilding requires new patterns of development, institutions, and governance structures be put in place to move PCEs forward to a time of peace, as pre-existing structures often contributed to the initial conflict. ${ }^{5}$ The Department of Peacekeeping Operations tackles four critical areas during peacebuilding: 'restoring the State's ability to provide security and maintain public order; strengthening the rule of law and respect for human rights; supporting the emergence of legitimate political institutions and participatory processes; and, promoting social and economic recovery and development'. ${ }^{6}$ These activities are designed to promote three inter-connected and potentially overlapping transitions in PCEs: security, socio-economic, and democratic. ${ }^{7}$ Three key features are believed to increase the success of UN peacebuilding activities: supporting national capacity development, fostering national ownership, and adhering to a common strategy. ${ }^{8}$ 
The security transition referred to above entails a variety of security sector reform activities, including criminal justice reform, to stabilize peace and reduce the likelihood of relapse to conflict. ${ }^{9}$ Criminal justice systems are often weak in the aftermath of conflict, and both prior to, and during the conflict, state actors may have been corrupt, abusing their powers, perpetuating human rights violations, and discriminating against vulnerable populations of citizens. Further, the state may have failed to prosecute those responsible for human rights violations, which are all realities that undermine public confidence and trust in justice administrations. ${ }^{10}$ Failure to reform criminal justice systems successfully to establish the rule of law in PCEs can lead to increased levels of crime and corruption, decreased public security, a lack of respect for human rights and support for peacebuilding efforts, and increased susceptibility to relapse back into conflict. ${ }^{11}$

A critical component in establishing the rule of law in PCEs is building a transparent, accountable, and ethical prison system that is capable of providing safe, secure, and humane conditions for prisoners, and 'which is built on principles of fundamental human rights, equality before the law, and the dignity of individuals'. ${ }^{12}$ Correctional reform has been defined as:

the process of changing a penal system to bring it into line with ... [the] rule of law and international human rights framework. It aims to ensure sanctions that are proportionate, non-discriminatory and rehabilitative. It aims to change prison institutions into places that respect individual human dignity, ensure that those imprisoned are afforded their legal rights, strengthen the appropriate use of alternatives to imprisonment and promote social reintegration of people who have offended. ${ }^{13}$

As Megan Bastick adds, correctional reform in PCEs may involve extensive reconstruction. ${ }^{14}$ In fact, the starting point for corrections reform activities following a period of conflict is often rebuilding and refurbishing prison facilities to ensure they can safely and securely detain prisoners. ${ }^{15}$

Corrections systems are believed to contribute to sustainable peace and promote human security by incapacitating violent offenders, rehabilitating offenders, and facilitating their reintegration into the community upon release. ${ }^{16}$ Promoting the rights of prisoners is also believed to increase citizen confidence and trust in the entire criminal justice system. ${ }^{17}$ Further, successful prison reform can decrease the likelihood that a culture of impunity will develop in a PCE. Failure to engage in effective corrections reform in PCEs may promote community instability and lead to poor management and an abundance of corruption within the correctional service. ${ }^{18}$ Despite being a key component in establishing the rule of law in PCEs, corrections reform is rarely identified as high priority in security sector reform activities, and if it is, the reform is usually poorly funded. ${ }^{19}$ Insufficient resource availability is a common challenge facing corrections systems in PCEs, especially considering the public would rather invest in issues that affect the country's entire population, such as the economy, education, and healthcare. ${ }^{20}$ International donor assistance can alleviate some of these financial concerns through donor-funded government and nongovernmental organization programs; however, donors may lack interest in investing in corrections reform because they do not want to be associated with inhumane practices should they continue to exist despite reform activities. ${ }^{21}$ When the international community becomes involved in these activities in transitional contexts, expectations should not be high, as development requires patience and even then, 'radical change [is] largely absent'. ${ }^{22}$

This brief review of the existing grey literature on liberal peacebuilding activities, and more specifically, corrections reform activities in PCEs, reflects lessons learned from previous missions and includes policy advice and recommendations to improve the success of future missions. Though the problem-solving approach is beneficial in identifying best practices for future peace operations, this approach lacks exploration of the underlying normative and ideological assumptions upon which peace operations are carried out. ${ }^{23}$ Peacebuilding activities are not value neutral, as they contribute 'to an ideology of world order that reflects and legitimizes neoliberal values, statecentrism and the economic structure of the international system' ${ }^{24}$ While it is beyond the scope of the current paper to explore in-depth, it is important to acknowledge and challenge the normative, liberal assumptions underlying peace operations and how for example, international interests often dictate intervention rather than the human security needs of the host country's citizens. ${ }^{25}$ Further, as Edward Newman and Roland Paris explain, it is necessary to situate peace operations in international relations to question how and why peace operations exist, rather than assume their existence is normal and that they maintain a natural place in global politics and order ${ }^{26}$ Peacebuilding is thus inherently political, including the decision to intervene in some environments and not others, what goals will 
be pursued, and what type of mission will be conducted. Furthermore, peacebuilding involves the international community exerting control and coercion over the host country, as demonstrated by their imposition of governance models, rules and regulations for economic assistance, and monitoring of elections. ${ }^{27}$

Given the relative absence of academic literature examining corrections reform activities undertaken during liberal peacebuilding missions in PCEs, the current study was designed to answer two questions: what are the dynamics of engaging in corrections reform activities within PCEs, and what challenges arose while implementing corrections reform activities within Kosovo in particular? Prior to presenting the case study and the findings that emerged from the data, the discussion turns to a review of the existing academic literature on corrections reform in PCEs.

\section{Literature Review: Corrections Reform in Post-Conflict Environments}

Existing research clearly highlights prison conditions and practices in transitional contexts and offers strategies (e.g., assessment, training, and vetting strategies) to address these conditions and practices (i.e. those that do not conform with international human rights standards). ${ }^{28}$ Jefferson discusses the need for research to go further and 'account for prison practice and not only keep accounts of (bad) prison practices' ${ }^{29}$ The studies discussed below examine these very factors and shed light on prison practices in transitional contexts. Similar to the recommendations produced in the grey literature about corrections reform in PCEs, these studies illustrate the importance of understanding the local context given the impact that local conditions and realities have on reform activities.

As Tomas Martin explains, 'human rights are negotiated, expressed, and implemented contingently', which results in diversity in how human rights materialize in practice in different environments. ${ }^{30}$ Martin's ethnographic fieldwork in men's prisons in Central and Eastern Uganda examined how international human rights standards were translated into practice in the Uganda Prison Service (UPS). ${ }^{31}$ Utilizing a bottom-up approach to his research, Martin engaged with local actors to examine what Olivier de Sardan labeled the "real appropriation" (the kind actually undertaken by local people)' rather than the '“ideal appropriation” (the kind dreamed of in project documents)' of the human rights discourse among UPS personnel..$^{32}$ Martin found that international human rights standards were transformed and produced by UPS personnel who attributed their own meanings - informed by the local context (including historical influences), dynamics, and existing practices, which involved the significant organizational change the service was undergoing - to the standards when implementing them. ${ }^{33}$ In particular, UPS personnel embraced international human rights standards as a means to 'gain more purchase on the legal technologies and reconceptualizations of prison management practices that affect them' ${ }^{34}$

Similar to Martin, Laura Piacentini was interested in the importation of human rights standards in Russia's prison systems and how prison officers understood the human rights agenda being enacted through technical assistance activities, the development of new legislation and policies, the reform of prison officer roles, and human rights for prisoners. ${ }^{35}$ Piacentini's interviews with prison officers in Smolensk and Omsk revealed that they viewed human rights as an imposition of Western standards and the officers 'were emotionally and intellectually cynical about the human rights rhetoric - many simply did not understand what it meant'. ${ }^{36}$ Piacentini thus questions whether penal reform of this nature can actually occur when those responsible for delivering human rights training to new cadets do not understand, or buy-in to, the importance of these principles and simply view the human rights agenda as a Western enforcement mechanism. ${ }^{37}$ Another example of how the local context and existing penal practices impact corrections reform activities and may impede substantial change from occurring comes from research conducted in Bosnia and Herzegovina by Andy Aitchson. ${ }^{38}$ Aitchison presented a case study of the work conducted by the Council of Europe as they sought to bring the conditions of detention for forensic psychiatric patients in Bosnia and Herzegovina in line with European human rights standards that emphasize prisoners' rights. ${ }^{39}$ In exploring how European instruments influenced local penal policies and practices, Aitchison found there was 'slow progress towards realizing a significant transformation' which he suggested was due to the fragmented political context in the PCE, which lacked one penal 'system', as multiple prison administrations existed in the country. ${ }^{40}$

Jefferson conducted eight months of ethnographic research in Nigeria in 2002, exploring the penal philosophy of the Nigerian Prison Service (NPS), the penal practices utilized within the system, and the dynamics of prison officer training. ${ }^{41}$ Similar to the work discussed above, Jefferson's findings raise questions about the practice of exporting 'global penal norms' to transitioning environments. ${ }^{42}$ The human rights approach to prison administration is generally applied to 'reform' recipient countries' corrections systems by way of targeting the behaviour of individual prison personnel (e.g., training-the-trainers) without paying due attention to the 'practices, processes and 
relations endemic' to prison systems. ${ }^{43}$ The manuals that were used during the 'training-the-trainer' initiatives in the NPS placed responsibility solely on individual corrections officers without addressing the overall legitimacy of the correctional institutions, the wider enabling environment, and how these factors impacted the implementation of skills and knowledge the individual officers learned during training. ${ }^{44}$ In examining training-the-trainer programmes in Nigerian prisons, Jefferson also found that while reform and rehabilitation were important to the prison officers, in this corporal-based training environment, officers viewed physical violence as vital to correcting prisoners' behaviour rather than human rights, which they viewed as 'counterproductive to correction and rehabilitation' ${ }^{45}$ Furthermore, Jefferson found that regardless of how much the NPS embedded human rights in penal policies and in their training practices, penal practices in the country also reflected the experiences officers had outside of the classroom, which did not always align with Western human rights standards. ${ }^{46}$

The issues discussed above illustrate the importance of conducting additional research outside of the Westerndominated scope that currently exists. To develop the field of international penology thoroughly, Tomas Martin, Andrew Jefferson, and Mahuya Bandyopadhyay argue that research - ideally, ethnographic - should be conducted to examine not simply the similarities and differences between Western and non-Western prisons but to examine 'what persists and what mutates within and across prison worlds' ${ }^{47}$ Martin et al. coined the term 'prison climate' to capture 'the idea that the prison itself is contested and changing' and to facilitate opportunities for comparative prison research. ${ }^{48}$ They define prison climate as: 'a set of general and prevailing conditions deeply characteristic of a particular site or system. The prison climate is a composite category, encompassing material conditions, values, relationships, and the political and moral economies - including the (ir)rationalities - that sustain them'. ${ }^{49}$ Having explored the academic literature examining corrections reform in transitioning contexts, it is to the case study of corrections reform in Kosovo that we now turn.

\section{The Case Study: The Kosovo Correctional Service in Post-Conflict Kosovo}

Kosovo is a small nation located in the Balkan Peninsula with a tumultuous history based on inter-ethnic violence and hostilities. Citizens in Kosovo spent most of the late 1990s experiencing a civil war, precipitated by nationalism and ethnic differences between Kosovar Albanians and Kosovar Serbians. This period of civil war was followed by a 78-day NATO-led air campaign against the President of Yugoslavia (Milošević) and his troops, which eventually led to their retreat from Kosovo. The international community intervened in Kosovo because they knew the Federal Republic of Yugoslavia's government was the force behind mass human rights violations against Kosovar Albanians and that they were unlikely to compromise. ${ }^{50}$ Following the retreat of Milošević and his troops, the United Nations Interim Administration in Kosovo (UNMIK) and the NATO-led Kosovo Force (KFOR) were established with UNMIK taking over as a transitional administration. ${ }^{51}$

When the NATO-led aerial bombing campaign ended, the international community faced significant challenges as they embarked on liberal peacebuilding activities in Kosovo. The quick withdrawal of Yugoslav military and police personnel created a security vacuum, which resulted in increased human, drug, and weapons trafficking, smuggling, corruption, organized crime, terrorism, and the criminalization of the economy. ${ }^{52}$ The events of the ethnic-fuelled civil war had severe consequences for the criminal justice system, as experienced Kosovar Serbians who held criminal justice posts during the 1990s fled to other countries after the NATO intervention due to the potential danger they faced at the hands of Kosovar Albanians. ${ }^{53}$ When UNMIK and KFOR arrived, the police could not provide safety and security for their people, the judicial system had collapsed, and the prisons could not be used to detain accused or sentenced individuals. ${ }^{54}$

Given the important role that corrections reform is believed to play in establishing the rule of law in PCEs, the decision was made to conduct a case study exploring the reform of the Kosovo Correctional Service (KCS). ${ }^{55}$ Further, as previously noted, there is also a relative lack of academic literature identifying lessons learned from experiences conducting corrections reform in PCEs when compared to the literature on the reform of other criminal justice sectors in these environments. ${ }^{56}$ Despite the absence of attention given to corrections reform activities in PCEs in the academic literature, an abundance of grey literature in the form of practical handbooks and toolkits has been produced by a variety of organizations. ${ }^{57}$ As Andrew Jefferson notes with respect to penal reform in transitional contexts (a term that encapsulates PCEs, as he uses the label in reference to states transitioning from war or transitioning from authoritarian to democratic governance), much of the existing literature is descriptive in nature, with little elaboration about the 'causes, dynamics or processes' that contribute to conditions and practices. ${ }^{58}$ 
The current study provides insights into the dynamics and challenges that corrections advisers experienced while engaged in corrections reform activities in Kosovo, arguably capturing some of the reasons they materialized and the practices that existed in the KCS. Through the use of first-person perspectives collected during in-depth interviews with 14 Canadian corrections advisers who participated in corrections reform activities in post-conflict Kosovo, this article contributes to a small body of academic literature investigating corrections reform in PCEs. The article's exploration of the dynamics and challenges involved in conducting corrections reform activities in Kosovo illustrates the need for the international community to give careful consideration to how they engage in corrections reform activities and attempt to export 'global penal norms' ${ }^{59}$ As discussed throughout, it is important to recognize UN and Western-developed human rights standards are not quickly, easily, and appropriately implemented in diverse prison environments where the local context shapes how human rights are imported and produced. ${ }^{60}$

The Penal Management Division (PMD) of the UNMIK Department of Justice was responsible for reforming and re-establishing the KCS, which included reforming its legal and operational framework to reflect international human rights prison standards. ${ }^{61}$ The PMD was also responsible for conducting a massive recruiting campaign, which involved training activities to ensure KCS personnel would possess the skills and knowledge to operate in accordance with these standards.$^{62}$ Further, the PMD was tasked with recruiting international corrections advisers, running the KCS facilities while the local capacities were being developed, and developing a strategy to transfer the operational authority eventually over to the KCS. ${ }^{63}$

UNMIK experienced difficulty locating adequate facilities to detain arrested individuals, as the correctional facilities - including the largest prison in Dubrava/Dubravë - were unusable due to inadequate cell space while others were unusable given NATO-inflicted cluster bomb and cruise missile damage to the physical infrastructure. ${ }^{64}$ Many correctional officials withdrew with Yugoslav security forces, so prison facilities contained neither correctional officers nor inmates (the inmates had been transferred to undisclosed locations in Serbia and Montenegro). ${ }^{65}$ Given these realities, UNMIK quickly realized they needed to initiate corrections reform activities but they experienced difficulties in doing so, as donor countries were hesitant to provide funds and corrections personnel. ${ }^{66}$

Due to the physical destruction of prison facilities during the conflict, pre-trial detainees were held in temporary prison facilities in the immediate aftermath of the conflict. These were typically army tents located in KFOR camps, with military personnel acting as correctional officers. There were concerns about this practice, as KFOR personnel did not possess the requisite skills and knowledge of international human rights prison standards to humanely fulfill correctional officer duties. ${ }^{67}$ This was also a concern when prison facilities started to open with International Civilian Police (CIVPOL) officers acting as prison officers due to the shortage of international prison officers. ${ }^{68}$ CIVPOL has been criticized for being corrupt and for having officers that came from jurisdictions where human rights were not always respected. ${ }^{69}$ The latter is not uncommon. More recently, Megan Bastick explained how African countries contribute the largest number of corrections gratis staff to mission, which is concerning given the poor prison standards in their home countries. ${ }^{70}$ Existing research examining the experiences of international police advisers also documents incidents of police advisers being deployed to mission from countries that do not follow the human rights standards they are supposed to teach the local residents. ${ }^{71}$ Further, interviews conducted with Western police officers who participated in international policing missions revealed their frustrations with poorly trained officers arriving from developing nations who may not speak English, and may be unable to complete basic tasks, such as drive a motor vehicle. ${ }^{72}$

\section{The Correctional Service of Canada in Kosovo ${ }^{73}$}

Through a joint Canadian International Development Agency-Correctional Service of Canada (CSC) initiative, CSC employees became corrections advisers in Kosovo. The objective was to develop a professional correctional service that respects and follows international human rights prison standards, respects the rule of law, and provides humane and fair imprisonment. ${ }^{74}$ CSC employees were seconded from the Government of Canada on three-month deployment cycles to work for UNMIK; the Canadian government paid their salaries, as they were gratis personnel for the UN. Additionally, some CSC officials took unpaid leave of absences from the CSC and went to Kosovo hired as UN employees on initially three-to-six-month UN contracts, many of which were extended. ${ }^{75}$ 


\section{Sample}

\section{Methodology}

Purposive sampling and snowball sampling were used in this study. A gatekeeper within the CSC emailed 33 of the 42 CSC employees whose names were listed on the organization's website for having participated in corrections reform in Kosovo: nine of these individuals participated in the study. Internet searches allowed the researcher to locate, contact, and interview two of the remaining nine individuals from the list for whom the gatekeeper did not have contact information. Through snowballing sampling with the aforementioned participants, three other participants were identified and participated in the study.

Data were collected during semi-structured, in-depth interviews that were conducted in 2012 and 2013 with 14 Canadian corrections advisers who participated in corrections reform activities in Kosovo while acting as: (a) CSC gratis staff during the years 1999 to 2003 (nine); (b) on-leave CSC personnel hired by UNMIK from 1999 to 2006 (three); and, (c) CSC personnel who did both, as they were initially CSC gratis staff and afterwards, they went on leave from the CSC to work for UNMIK (two). Every participant went to Kosovo on at least one occasion for a period of approximately ten days to four years. Of the 14 participants, 12 were males and 2 were females. Five retired CSC officials, seven current CSC officials, and two ex-CSC officials employed by other organizations, were interviewed.

\section{Procedure}

The Study Information and Informed Consent document that was sent to participants when their participation was requested included the research objectives, what was required of participants, ethics-related issues, examples of questions they would be asked, and how the findings would be distributed. Those who agreed to participate in the study were asked to complete a written informed consent form (current CSC employees) or were asked to provide verbal informed consent (the remainder of the sample). ${ }^{76}$ Participants were told they could withdraw from the research process at any time without facing negative consequences and at which point in time, the written or electronic data from their interviews would be destroyed. None of the participants withdrew their participation from the study.

A semi-structured interview schedule was designed and used to elicit corrections advisers’ insight and experiences about their time in Kosovo. Participants were asked 22 open-ended questions to capture their subjective meanings about the dynamics and challenges of conducting corrections reform in a PCE, and their opinions about the use of UN and Western-developed frameworks in Kosovo and other PCEs. ${ }^{77}$ Interviews with the corrections advisers were between 60 minutes (Michelle/Rick) to 220 minutes (Brad) in length. In total, I conducted nine face-to-face interviews with participants from across Canada, one Skype-assisted computer interview where the participant and I were face-to-face with one another but not in the traditional manner, and four telephone interviews. All of the 14 participants agreed to have their interviews recorded and each participant was offered a copy of her/his written transcripts in case they wanted to remove something s/he had said. Only one of the 14 participants requested her/his interview transcripts and s/he did not make any revisions and/or retractions.

\section{Data Analysis: Coding}

The data were analysed using a qualitative computer program called NVivo10, beginning with the process of open coding (in vivo coding), where I read through all 612 single-spaced pages of transcribed notes to assess what could be inferred from the data without using a pre-determined coding schedule. At the end of the open coding process, 80 codes, with the number of references located in each code varying from 2 to 57, were identified as relevant and meaningful in exploring the research questions. During the next stage of data analysis, axial coding, concepts were created and interrelationships appeared by establishing connections between the categories that emerged during open coding. Themes were identified as the data were read and re-read during selective coding until no further themes could be identified. Eighty codes were identified during open coding, which during axial and selective coding, were collapsed into 42 themes: five of the main themes are discussed in the present work. 


\section{Findings}

Prior to presenting the five main themes that emerged during the data analysis of interviews with Canadian corrections advisers, corrections reform is defined from the perspective of the participants given the multitude of definitions that are frequently attached to post-conflict peacebuilding activities. Many participants indicated that corrections reform is about promoting a change in values from the past: 'Reform to me means a restructuring or realigning of processes in relation to a changed value system ... We are not just trying to reconfigure the lineup of the ducks; we're trying to come up with a new target to shoot at' (Chris).

Participants indicated that corrections reform, in addition to requiring a change in values, requires a change to bring corrections systems in line with international human rights standards. For example, James noted that reform:

would be changing the conditions, kind of bringing it up to international standards that would make the environment in the prison more conducive to better training for the staff, better living conditions for the inmates, better healthcare for the inmates, making sure the inmates got treated fairly, making sure that staff got looked after, and giving them all the tools that we could, to make their lives and the inmates' lives better, and in doing that, also making it safer for everybody.

Introducing international human rights standards into the KCS was a priority due to concerns with previous prison practices:

Our goal was very noble in terms of developing training that was based on a more modern model respective of human rights, and training staff to work under such a model. Because prior to that, the story we heard when we were there was that it wasn't a very fair model, it wasn't very respectful of human rights, it was an old Yugoslavian format that quite frankly, was very corrupt. (Steve)

\section{Understanding the Local Context}

Each of the participants explained how they had conducted their own preparation, received organizational (typically referred to as minimal) preparation, or had both, prior to departing for Kosovo:

I began doing a little bit of research on my own because I like knowing what I'm getting into. My learning was partly what had been in the media, and I picked up a few books along the way; just to kind of get a background on Kosovo, a little bit of history on Kosovo. So I did a lot on my own, and the orientation that we took part in immediately before deploying, kind of tied everything together for me and was more than sufficient... I don't think we could've been better prepared for the damages of war. (Chris)

Multiple participants described how their understanding of the situation changed when they arrived in Kosovo:

I find in those situations, an orientation will prepare you but it's not always accurate 100 per cent in terms of what's happening on the ground because situations are forever evolving. We had basic knowledge; but when you get there, you just learn things from a different perspective. When you get an orientation, you try to set it up so that it's a neutral perspective. But when you get there, and you live with Kosovar Albanians who've been repressed in their minds - and not just in their minds, but also in reality, for many years - you get a very different perspective on things. (Steve)

Multiple participants discussed how they learned very quickly about the local correctional context, recognizing organizational and cultural differences between the CSC and the KCS. Participants worked towards developing policies and practices that as much as possible, respected the local processes and values, which many participants illustrated by discussing this example: 
In Canada, our ideal is single-bunked accommodation, one cell per inmate. For us it's a concept that is well understood in our world, and it's a concept that's served us well organizationally both from a security frame and human rights frame. In Kosovo, it was quite reasonable to see twenty fellas to a cell; to them, that was their norm. To put a guy into a single cell was absolutely torturous for them. So, I mean, you abandon that concept, put it aside, but you don't abandon the concept of ensuring these men are fed, that they're given water, that they're given the opportunity for exercise and some fresh air. So it's never as pure as saying, 'We're going to instill these values', as you have to work within the existing culture, you have to work with the existing parameters, recognizing that at the end of the day, your support to Kosovo is to build their own systems that serve their interests, with as many principles of human rights into it as you can... So you know, cultural aspects, societal norms, whatever word you want to use, those are some of the things you want to contextualize to the environment, and not adopt a position that is 'Canada's way or no way'. (George)

'There's Nothing Sexy about Corrections' (Michelle)

A common theme throughout the interviews was that the UN had not given adequate attention and resources to corrections reform activities. As Tom explained: 'The biggest problem we had was the fact that the UN had no idea about corrections whatsoever. They basically thought this little ragtag team could somehow, within a couple of months, open all of these prisons, and they didn't have any conception of what was involved.'

Participants spoke about how the international community preferred to engage in reform activities that would benefit the non-offending public, so their efforts were focused on those areas instead:

The sexier areas were the ones countries wanted to do: to rebuild a hospital, rebuild a school, rebuild the infrastructure, rebuild housing, you know? The correctional one isn't one that's exactly too sexy because you know; well, these are the bad guys, why would we be putting money and the support into them? (Tom)

Participants described how even in comparison to the police and judiciary, corrections reform was not on the 'giant radar screen' (Tom), despite its role in establishing the rule of law. They spoke about how the lower status afforded to corrections reform and officers created operational challenges for them in terms of recruiting and retaining corrections officers:

When the UN came in and committed, they brought in policing experts. There was a delay though - they were behind the game in that way - in bringing in correctional experts. Also, salaries differed between a correctional officer and a police officer - the difference was quite stark... You have to pay these people equivalent because you'll never be able to maintain correctional officers if people see the opportunity for a government job over there, with similar training, but making more Deutschmarks a month than this guy... Everybody's going to leave. (George)

If you look at the correctional officers, they were making 150 and up to 200 Euros a month, and then the Kosovo Police Service (KPS), they were 500 plus, so the correctional officers were made to look like a non-important part of the justice system. The locals that were getting say, 150 dollars a month, when they looked at the wages of the police service, who were making say 500, they're all supposed to be part and parcel of the justice system, they go well, 'They don't care about us, we're not as important as them', so did it lead to corruption? Sure. (James) 
This is an author-produced, peer-reviewed version of this article. The final, definitive version of this document can be found online at International Peacekeeping, published by Routledge. Copyright restrictions may apply. doi: 10.1080/135333312.2015.1041383

\section{For the Love of Money}

Participants indicated corruption was one of the most defining features of post-conflict Kosovo, which impacted corrections reform activities, and was at times, said to be fuelled by the UN's decision-making practices:

One of the real heartbreakers, eye-openers, jaw-dropping moments in my life, that I have never really been the same since, was the day we were told that we were going to pay our wardens 300 Deutschmarks a month. I said, 'Three hundred Deutschmarks a month? Why would we pay somebody \$300 a month?' 'Well, that's what the Police Chief is getting'. And I'm going, 'Oh, really? I can tell you this right now; this will not even cover the Police Chief's Mercedes payment!' We actually managed to track down one of the previous Police Chiefs, and ... we eventually worked him to the point where we go, 'Tell me, factoring all of your income in, approximately how much money did you make?' It was around \$110,000 a year, which would've been standard fare for Police Chiefs in Europe, Eastern Europe. Well if you're going to pay the guy, if the guy expects to make $\$ 110,000$ a year, and you are paying him in essence, $\$ 4,000$ a year, where are the remaining $\$ 106,000$ going to come from? Well, from creative management. That's when I realized, 'Wait a second; this is wrong. This isn't just wrong; this is designed, intentional, stupid wrong'. There is something that is just - I'm searching for the right word - there is something toxic about this thinking and to say, 'Well we have to do it this way here' is to simply say, 'I guarantee we're going to build in the same level of incompetence and corruption’. (Chris)

Although agreeing that corruption occurred and was likely influenced by the UN's salary choices, a couple of the participants explained how they thought corruption actually reflected the culture in Kosovo - years of corrupt practices - and it would not be quickly and easily thwarted:

They were all underpaid, doesn't matter if you were a warden or a corrections officer ... I think that it had a big influence on corruption because again, corrections officers, we knew that some were taking unauthorized things into the prison for inmates and getting paid for it. So, we knew that was happening, and I wouldn't be surprised quite honestly, although I don't have any proof, that wardens knew that it was happening as well, and probably got a cut of that. So the money, the low salaries, probably didn't do anything to stop corruption or to curb it, but again, I go back to, well I don't care in my mind, if you pay them $\$ 100,000 /$ year like you do in Canada, it's part of who they are, it's part of their society, and people do corrupt things not just for money, but they do it for other reasons as well. I think you would continue - if they had been paid those big salaries - I think you would continue to see corruption happen on a certain level. (Steve)

\section{'I Hate Putting up with Incompetence' (Bill)}

Most participants discussed the challenges of providing humane and safe confinement for prisoners, particularly in the immediate aftermath of conflict when soldiers were staffing prisons, including makeshift military prisons that were nothing more than military tents. Thus, one of the main priorities in the early days was developing a strategy to take over from the soldiers:

The troops were guarding, I think it was around 250-some prisoners and you have to remember when the military goes into these particular types of situations, guarding prisoners isn't their kind of work, number one. Number two, it's not their training; they're trained to be soldiers, and any time you take soldiers away from their role, you lessen your true capabilities to do real work. (George) 
This is an author-produced, peer-reviewed version of this article. The final, definitive version of this document can be found online at International Peacekeeping, published by Routledge. Copyright restrictions may apply. doi: 10.1080/13533312.2015.1041383

Later on, CIVPOL officers became involved in staffing KCS institutions until local residents could safely take over; this practice created challenges for providing safe and humane imprisonment. Participants explained how CIVPOL officers arriving in Kosovo had to do three-month stints with corrections, which some international police officers did not want to do. This practice created challenges for on-leave CSC employees managing KCS facilities:

Just working with police in general, never mind what country they are from, police, they make bad correctional officers. They don't really get that part of the justice system ... Also, when you're talking about reform, how can you do a lot of reform when you're dealing with staff rotating all of the time? They're the worst police officers that show up in the country, they're assigned to a prison, they hate it, and they only have to stay three months. So can you imagine? Seventy officers, every day, officers were coming and going. (Brad)

\section{'I didn’t meet too Many Experts’ (Dean)}

Participants noted the lack of expertise among international advisers, who were also referred to as 'experts'. George offered insight about the definitional problems associated with the word:

When you use the word 'experts', there are different definitions; across different jurisdictions, across different countries, about what constitutes an expert, and the view in the eyes of someone else. It's a loose definition ... I'd never really say anything untoward about anybody who basically is giving up their time, capacity, and their talent to do the things they need to do. But at the same time, some of the people that I saw, if they were even seen to be classified as experts, they wouldn't fit my frame of reference for an expert, and I'm sure in the eyes of some that met me, I wouldn't meet their definition.

Participants described how other international corrections advisers seemed to lack concern for developing the local capacities and improving the environment for the local residents, which was concerning to them, as they recognized that sustainability is fostered through capacity development activities and tailoring reform activities to the local environment. James reflected on how frustrating it was that some 'experts' were simply going through the motions:

I've known experts over there that were in the mentoring process and the skills that they were trying to pass on, or the way they were mentoring the locals, wasn't really doing 'em any good. They would basically go through the motions; they didn't care whether the locals that they were mentoring understood what they were trying to do. A lot of them had the mentality that they're not well educated, they're not the brightest, and that type of thing, and so they didn't put a lot of effort into it. But they went over there as mentors and they failed in not doing what they were sent over there to do. That was kind of an injustice to the locals and we saw that quite a bit, and it was very frustrating. I know when we worked with the locals, we spent a lot of time with them, and we were really interested in making sure that they grasped what they needed to do as a Director or a Supervisor. We spent a lot of time with them going over different policy, and how to deal with the inmates because they came from a different culture.

Rick spoke about the inappropriate training methods that were used by international experts responsible for training local residents and developing their capacities:

The PMD's idea of involving the locals in management was we'd have these monthly management meetings and we'd all sit around the table. All the ones that were allegedly being trained to take over from us would sit around the back of the room, and someone would translate for them what was being said. To me, that wasn't a very big step forward. That was the extent of what I saw of involving them in it. 
Although there was some suggestion that international advisers may intentionally undermine reform efforts to secure their long-term relevance in Kosovo, John expressed his belief that it was unintentional:

What struck me was that the people I had to deal with, they didn't have to potentially try to sabotage anything to stay longer, they were causing, wreaking such havoc, just themselves. If they were stalling things, it was just because of how they were dealing with situations.

Participants attributed the lack of expertise among international advisers to nepotism and the hiring processes undertaken by the UN:

One of the biggest things I found, and I was really disappointed with, was that there was the sense of the Old Boy's Club; looking after your buddy. The people in charge of the corrections mission were British and what they would do because they know friends from their penal system - is they would go to bat for them to get them over. They'd be on the interview hiring panels, and they'd get selected, and come over... That was a fairly common thing: the nepotism, the looking after their buddies, and coming over because of them. Some of them, they didn't really care what happened in Kosovo; they were there for the money because the money was fairly good. (Michelle)

Participants voiced their frustrations with the UN selection process, suggesting that the UN has so many countries under its umbrella that pay into the UN, that they are obligated to send a certain number of personnel to each mission. Participants spoke about their lack of skills, as they came from systems that did not nurture the values that the PMD was trying to establish within the KCS:

You get a guy from South Africa who, I mean, before apartheid, they ruled with brutality in their prisons. I mean some of the things like the way he had of managing, I was horrified. But that was his management, so how are you going to get him to have some empathy and respect, dignity, and all that kind of stuff? (Brad)

A few participants explained how many internationals posted in the KCS could not drive, had poor writing skills, and/or some could barely speak English. James explained that when you received these individuals - say as CIVPOL officers who arrive to fill posts as corrections officers - 'you weren't going to get anything out of them; they were filling a post and basically, that was it'.

\section{Discussion}

Relatively little research has been conducted to examine corrections reform undertaken during peacebuilding missions in PCEs. As previously mentioned, most of the existing literature exploring corrections reform in PCEs is in the form of grey literature, such as handbooks, toolkits, working papers and the like. The objective of this study was to interview corrections advisers to explore the dynamics and challenges they experienced when conducting corrections reform in post-conflict Kosovo. The strength of this study was that the use of in-depth semi-structured interviews allowed for investigation of the constructed realities of the 14 Canadian corrections advisers, providing a high degree of information gathering and capturing rich quotations, thereby making a significant contribution to the limited body of academic literature examining corrections reform in PCEs.

Five main themes emerged from the data with respect to the dynamics and challenges that Canadian corrections advisers experienced when conducting corrections reform in post-conflict Kosovo. Prior to discussing these themes, it is important to mention that participants' definitions of corrections reform reveal that these activities were designed to import 'global penal norms' into the KCS with the belief that such norms would improve the system for those working and living in the system. ${ }^{78}$ 
Participants discussed the necessity of engaging with the local residents to develop an understanding of what Martin et al. have recently termed the 'prison climate' that exists in the host country. ${ }^{79}$ Understanding the 'prison climate' the 'material conditions, values, relationships, and the political and moral economies - including the (ir)rationalities - that sustain them' requires extensive engagement among international actors and local personnel. ${ }^{80}$ This engagement facilitates understanding and may lead to the development of reform strategies that are defined by the local residents, and thus, may be more relevant and likely to lead to sustainable change. ${ }^{81}$ The participants recognized that as Jefferson explains, prisons are 'sites of contestation and ambiguity', and as such, they tweaked their reform standards and strategies to accommodate local practices and values (e.g., those around communal living arrangements). ${ }^{82}$

Similar to the recommendations made in the existing grey and academic literature, the findings that emerged from the data reveal the importance of accounting for the local context when engaging in corrections reform activities in transitional environments. While the grey literature discusses the importance of recognizing the local context as a best practice for engaging in corrections reform activities in PCEs, the existing academic literature, including the current study, suggests that practitioners with their boots on the ground often experience uncertainty and encounter challenges in achieving this best practice when implementing UN and Western-developed human rights standards in PCEs. These uncertainties and challenges sometimes require practitioners to deviate from strict adherence to their organizations' best practices discourse, as the local conditions and realities impact the importation and production of human rights in PCEs. ${ }^{83}$

Corruption is a common feature in PCEs and it often increases throughout the core period - the immediate weeks and months following the conflict when societies are transitioning from authoritarian leadership to democratic governance. ${ }^{84}$ Corruption was said to be both woven into the social fabric, as well as reflect the UN's poor remuneration of corrections staff. The current findings suggest the UN needs to reconsider staff salaries if they are going to curb corrupt practices among corrections personnel. This finding is supported in the PCE police reform literature, which documents how low salaries increase bribery and corruption within police services ${ }^{85}$ Corruption among criminal justice personnel may also lead to increases in violence and criminal behavior in PCEs. ${ }^{86}$ Findings from a 2011 report suggest that corruption continues to persist in the KCS, among allegations of prisoner abuse and favoritism, which gives credence to participants' concerns that corrupt practices within the KCS would not be easily changed, as the corruption reflected larger systemic and cultural issues. ${ }^{87}$ It is important to target capacity development activities at the individual level, organizational level, and towards the enabling environment because individuals and organizations function in environments that may encourage positive change and capacity development (enabling environments), or, in environments that may impede capacity development activities due to environmental constraints. ${ }^{88}$

Many of the challenges participants spoke about have been addressed in existing grey literature (e.g., the UNODC's Handbook for Prison Leaders) and focus on three primary issues; first, is that the low priority afforded to corrections reform activities creates obstacles in securing financial resources. ${ }^{89}$ Corrections advisers in Kosovo experienced particularly acute challenges in securing donor attention and funding because donors wanted to engage in 'sexy' areas of reform - such as rebuilding hospitals and schools. As the International Corrections and Prisons Association noted, UNMIK was the very first mission where corrections personnel were asked to become involved in peacebuilding, and as participants explained, the UN had no idea what corrections reform would entail, or the resources that were required. ${ }^{90}$ The low status afforded to corrections reform created challenges for corrections advisers in recruiting and retaining officers and contributed to corruption because KCS officers were paid less than KPS officers.

The second challenge reflects the need to provide safe and secure confinement for prisoners. Participants spoke at length about the challenges they experienced in providing safe and secure confinement in the KCS given that untrained international police and military personnel were filling correctional officer posts. One of the problems that typically plague corrections systems in PCEs is unskilled personnel, or an absence of personnel. ${ }^{91}$ CSC personnel were responsible for recruiting and training personnel for a multi-ethnic KCS to fill those positions left by experienced Kosovar Serbians who previously held criminal justice positions and fled to other countries after the NATO intervention. ${ }^{92}$ Due to an absence of suitable local corrections personnel to provide safe and secure confinement for a mixed prisoner population in an environment characterized by ethnic-fuelled conflict, KFOR and CIVPOL took on correctional responsibilities. Participants voiced concerns about the abilities of these individuals to provide humane imprisonment, as these officers did not have knowledge of, or experience with, international human 
rights prison standards, which are concerns Hansjörg Strohmeyer also voiced. ${ }^{93}$ Another challenge was that CIVPOL officers were being deployed to Kosovo from countries that did not necessarily have a good record of respecting human rights in general. These findings are consistent with literature exploring police reform in PCEs; international police advisers have arrived in PCEs from countries that do not practise the human rights standards they are supposed to teach the local residents. ${ }^{94}$ It is also not uncommon for international corrections advisers to be deployed to mission from countries with less-than-desirable human rights prison practices. ${ }^{95}$

The third challenge arose with respect to human resource issues. The bureaucratic structure of the UN and the incompetence of UNMIK corrections personnel created challenges for CSC personnel. There were concerns about UNMIK corrections advisers because they appeared to have a poor understanding of the local dynamics, they used ineffective training strategies, and they seemed to lack interest in promoting local ownership or developing the local capacities. The current findings are similar to existing cross-sectional criminal justice literature that documents the challenges associated with poorly trained staff arriving in host countries with poor skillsets to effect change and with little experience with, or knowledge of, comparative law or comparative analysis of criminal justice systems to develop strategies that are appropriate and workable in the local context. ${ }^{96}$

\section{Limitations and Future Research}

A limitation of this study was that the sample included primarily men (12 out of 14 participants) from one correctional service. Thus, further research should explore the experiences of women in peacebuilding missions, and the dynamics and challenges experienced by corrections personnel working for a variety of correctional services, including individuals from local systems. This case study utilized a small sample, so generalizability of the findings is not possible. However, exploratory research about corrections reform in PCEs was deemed necessary given the relative absence of research of its kind and because the research objectives were best met by utilizing nonprobabilistic sampling techniques.

Future research exploring corrections reform activities in PCEs should involve local actors who participate in the process given that they are responsible for long-term change and peace. This research may include their experiences with internationals (similar to Béatrice Pouligny's anthropological study investigating what local residents think of peacekeepers), the knowledge-transfer process and training methodologies that are utilized (similar to Jefferson's ethnographic research exploring correctional officer training in Nigeria), or correctional officers' perceptions of the relevance of Western human rights standards in their countries (similar to Piacentini's study exploring prison reform in post-Soviet Russia through participant observation and interviews and Martin's ethnographic work examining the importation of international human rights into practice in Uganda). ${ }^{97}$

Future research should also be conducted to explore the correctional philosophies and political agendas, roles, and activities of organizations that deploy personnel to missions. This research should explore whether these organizations participate in peacebuilding to conduct justice reform to establish respect for democracy, human rights, and the rule of law, or, if they participate for political reasons (i.e., to garner organizational support nationally and internationally). The lack of donor evaluations conducted on the multitude of activities undertaken during peacebuilding missions suggests that donor governments are not genuinely interested in learning 'what works' when it comes to official development assistance activities and that post-conflict peacebuilding activities may in fact be an exercise in political posturing and 'waving the flag' because they seem unconcerned with learning more about the micro-level dynamics and challenges involved in the work, and the overall impact of their human and financial investments. Future research should therefore evaluate the success of corrections reform activities in PCEs. Given the human and financial consequences of engaging in post-conflict peacebuilding activities, it is necessary that future research be carried out to evaluate their success and go beyond merely identifying the number of personnel that go to mission and consider success in terms of larger outcomes, such as establishing respect for human rights, the rule of law, and effective governance structures.

Another important avenue for future research in PCEs is exploring why these nations' punish, whom they punish, and the effectiveness of the punishment they administer, which are all missing from discussions about corrections reform in PCEs. ${ }^{98}$ These questions are particularly important in PCEs where Western standards are forced upon them, often with limited attention being given to local modes of customary justice, which may be more suited to the cultural beliefs and social mores. ${ }^{99}$ Unfortunately, local actors often have little voice in describing what peace should look like within their country. ${ }^{100}$ 
While both the grey and academic literatures emphasize the importance of tailoring reform activities to the local context, it appears as though the two literatures affix different meanings to this term and how to go about ensuring reform activities account for the local context, which necessitates additional research. Future research should also explore the tensions that exist between the best practices discourse and the realities practitioners experience on the ground when implementing these best practices.

\section{Policy and Practice Implications}

This study contributes to the growing academic literature exploring corrections reform in PCEs, and as such, it is important to discuss the policy and practice recommendations that emerged from the data. Some of these recommendations have been made elsewhere, including in the UN Secretary General's eight principles to be followed while conducting rule of law reform activities; however, it is important to reflect upon these recommendations with specific reference to corrections reform activities given their relative absence in the academic literature. ${ }^{101}$ They also merit repeating because despite the fact these recommendations have been documented elsewhere, there is concern that some of these lessons continue to remain unlearned. Based on the findings that emerged from the data, the following policy and practice recommendations have been made for those involved in corrections reform activities in transitioning environments:

\section{Ensure the Local Context Informs Corrections Reform Decisions}

One of the most prominent themes that emerged from the data is the importance of understanding the local context when conducting corrections reform activities. Pre-deployment training, and training upon arrival in the host country, is required to ensure participants understand the unique contextual factors in the transitional environment. Attention should be given to historical accounts of the conflict, existing conflict drivers, and the local criminal, political, social, cultural, and correctional context. As noted, no amount of pre-deployment training will fully prepare personnel for what they experience abroad; however, pre-deployment preparation ensures personnel are as informed as possible about the existing realities in the transitional environment. Further, it is important to engage with local personnel to learn about the unique 'prison climate' that exists in the host country and use this engagement and understanding to develop reform strategies that are workable in the local context. ${ }^{102}$

\section{Foster Local Ownership}

Local ownership should be encouraged early on in the peacebuilding process by involving local actors in the design, implementation, and management of corrections reform activities. Local ownership of corrections reform activities enhances the mission's overall credibility, encourages support for reform activities, increases the legitimacy of the emerging corrections system, and encourages long-term sustainability of reform efforts, as local actors will know how to manage when the international community exits. ${ }^{103}$

\section{Develop Local Capacities}

Capacity development should begin early on in the peacebuilding process by engaging with the local residents and having them participate in the assessment of the local capacities and needs. Further, local residents should be involved in developing the plan of action to strengthen dormant capacities and develop new ones, implementing the plan of action to foster local ownership, and evaluating the capacity development plan to determine if the outcomes and impacts were met (which reflects the United Nations Development Programme's (UNDP) Capacity Development Process). ${ }^{104}$ In assessing the local capacities, it is important to consider local customary modes of justice that may be more appropriate for use in PCEs than Western democratic models.

\section{Exercise Patience}

The current findings suggest the importance of international corrections advisers remaining flexible in conducting their work by learning from the local residents, and adapting their practices to accommodate cultural differences and contextual characteristics. Participants also spoke about the importance of exercising patience while implementing UN and Western-developed principles and standards in Kosovo. Patience is important because reasonable timelines may mean internationals are less inclined to take over reform activities to ensure donor deadlines are met, which means there is a greater likelihood that local ownership will be fostered, and local capacities, developed. Therefore, 
This is an author-produced, peer-reviewed version of this article. The final, definitive version of this document can be found online at International Peacekeeping, published by Routledge. Copyright restrictions may apply. doi: 10.1080/13533312.2015.1041383

reform might be more about planting the seeds of change than it is about overhauling the system. The weaker the corrections system, the greater the amount of time that is required to reform it, as the requisite reforms may be extensive and involve rebuilding the physical infrastructure. Time is of the utmost importance to ensure a bottom-up approach to reform activities occurs.

\section{UN: Accord High Priority and Funding to Corrections Reform}

Corrections reform cannot continue to be overlooked and under-prioritized during peacebuilding missions. The UN should prioritize corrections reform activities given these activities are believed to play a key role in establishing the rule of law in PCEs and promoting human security and citizen trust while decreasing community instability and the likelihood that a culture of impunity will develop. Adequate human and financial resources must be dedicated to corrections reform activities in PCEs and further; the UN has to develop their corrections reform capacities. Making corrections a priority includes paying corrections officers adequately to thwart corrupt practices and facilitate the recruitment and retention of corrections personnel.

\section{UN: Revise Deployment Practices}

One of the most prominent themes that emerged from the data was the participants' disillusionment with UN personnel - both UNMIK corrections advisers and CIVPOL officers. Thus, the UN should consider revising their deployment practices and implement conditions that restrict participation for those going to mission to reflect the duties personnel are required to fulfill in mission and the knowledge they are expected to teach others (e.g., international human rights standards). Further, the UN should develop better strategies to educate internationals about their roles in PCEs, including information about how to engage effectively the local residents in the reform process, develop their capacities, and promote local ownership.

\section{About the Author}

Danielle Murdoch is an Assistant Professor in the Department of Criminal Justice at Boise State University.

\section{Notes}

${ }^{1}$ United Nations Peacekeeping, 'List of Peacekeeping Operations 1948 - 2013', United Nations Peacekeeping, Apr. 2014 (at: www.un.org/en/peacekeeping/documents/operationslist.pdf).

${ }^{2}$ Anne Holohan, Networks of Democracy: Lessons from Kosovo for Afghanistan, Iraq, and Beyond, Stanford, CA: Stanford University Press, 2005.

${ }^{3}$ Max Boot, 'Neither New nor Nefarious: The Liberal Empire Strikes Back', Current History, Vol.102, No.667, 2003, pp.361-366.

${ }^{4}$ Heather Hrychuk, 'Combating the Security Development Nexus? Lessons Learned from Afghanistan', International Journal, Vol.64, No.3, 2009, pp.825-842, p.828.

${ }^{5}$ Derick W. Brinkerhoff, 'Rebuilding Governance in Failed States and Post-Conflict Societies: Core Concepts and Cross-Cutting Themes’, Public Administration and Development, Vol.25, No.1, 2005, pp.3-14.

${ }^{6}$ Department of Peacekeeping Operations, 'United Nations Peacekeeping Operations: Principles and Guidelines', New York: Department of Peacekeeping Operations, 2008, p.25.

${ }^{7}$ Béatrice Pouligny, Peace Operations Seen from Below: UN Missions and Local People, Bloomfield, CT: Kumarian Press, 2006.

${ }^{8}$ United Nations Peacebuilding Support Office, 'UN Peacebuilding: An Orientation', New York: United Nations, 2010; United Nations Secretary General, 'Guidance Note of the Secretary-General: UN Approach to Rule of Law Assistance’, DPKO, OROLSI, Apr. 2008 (at: www.unrol.org/files/RoL\%20Guidance\%20Note\%20UN\%20Approach\%20FINAL.pdf).

${ }^{9}$ Michael Barnett, Hunjoon Kim, Madalene O’Donnell, and Laura Sitea, 'Peacebuilding: What Is in a Name?', Global Governance, Vol.13, No.1, 2007, pp.35-58; Vincent Chetail, 'Introduction: Post-Conflict Peacebuilding Ambiguity and Identity’, in Vincent Chetail (ed.), Post-Conflict Peacebuilding: A Lexicon, New York: Oxford University Press, 2009, pp.1-33. 
This is an author-produced, peer-reviewed version of this article. The final, definitive version of this document can be found online at International Peacekeeping, published by Routledge. Copyright restrictions may apply. doi: 10.1080/13533312.2015.1041383

${ }^{10}$ Peter Albrecht and Lars Buur, 'An Uneasy Marriage: Non-State Actors and Police Reform', Policing and Society, Vol.19, No.4, 2009, pp.390-405; Office of the United Nations High Commissioner for Human Rights, 'Rule-of-Law Tools for Post-Conflict States: Mapping the Justice Sector', New York and Geneva: Office of the United Nations High Commissioner for Human Rights, 2006.

${ }^{11}$ Louise Arbour and Antonio Maria Costa, 'Foreword', in Vivienne O’Connor, Colette Rausch, Hans-Joerg Albrecht, and Goran Klemencic (eds), Model Codes for Post-Conflict Criminal Justice: Volume I Model Criminal Code, Washington, DC: United States Institute of Peace Press, 2007, pp. xxi. -xxii.

${ }^{12}$ Department of Peacekeeping Operations, 'Prison Support Guidance Manual', UN Peacekeeping Operations, Jan. 2006 (at: www.unrol.org/files/FinalPrisonGuidanceManual20April2006.pdf), p.1.

${ }^{13}$ Megan Bastick, 'The Role of Penal Reform in Security Sector Reform', [Occasional Paper No.18,] Geneva: Geneva Centre for the Democratic Control of Armed Forces, 2010, p.7.

Megan Bastick uses the term 'penal reform' throughout her report about the role of penal reform in security sector reform, although she acknowledges that the USA and Canada use the term 'correctional reform' instead. Given that the participants who were interviewed for this project are Canadian, 'correctional reform' was used throughout the study and in the final presentation of the results.

${ }^{14}$ Ibid.

${ }^{15}$ United Nations Office of Drugs and Crime and United States Institute of Peace, 'Criminal Justice Reform in PostConflict States: A Guide for Practitioners’, New York: UN, 2011.

${ }^{16}$ Department of Peacekeeping Operations, 'Corrections Update: Volume 4', Department of Peacekeeping Operations, Dec. 2012 (at: www.un.org/en/peacekeeping/publications/Corrections2012.pdf).

${ }^{17}$ Department of Peacekeeping Operations, 'Corrections', Department of Peacekeeping Operations, n.d. (at: www.un.org/en/peacekeeping/issues/ruleoflaw/corrections.shtml).

${ }^{18}$ Bastick (see n.13 above).

${ }^{19}$ Department of Peacekeeping Operations (see n.17 above); Office of the United Nations High Commissioner for Human Rights (see n.10 above).

${ }^{20}$ Organization for Economic Co-operation and Development, 'The OECD-DAC Handbook on Security System Reform (SSR): Supporting Security and Justice’, Paris: Organization for Economic Co-operation and Development, 2007; United Nations Office of Drugs and Crime, 'Handbook for Prison Leaders: A Basic Training Tool and Curriculum for Prison Managers Based on International Standards and Norms', New York: UN, 2010.

${ }^{21}$ Organization for Economic Co-operation and Development (see n.20 above); Bastick (see n.13 above).

${ }^{22}$ Andrew M. Jefferson, 'Prison Officer Training and Practice in Nigeria: Contention, Contradiction, and ReImagining Reform Strategies’, Punishment \& Society, Vol.9, No.3, 2007, pp.253-269, at p.254.

${ }^{23}$ Roland Paris, 'Broadening the Study of Peace Operations', International Studies Review, Vol.2, No.3, 2000, pp.27-44; Alex, J. Bellamy, 'The "Next Stage” in Peace Operations Theory?', International Peacekeeping, Vol.11, No.1, 2004, pp.17-38.

${ }^{24}$ Michael Pugh, 'Peacekeeping and IR Theory: Phantom of the Opera?', International Peacekeeping, Vol.10, No.4, 2003, pp.104-112, at pp.110-111.

${ }^{25}$ Bellamy (see n.23 above).

${ }^{26}$ Edward Newman, “'Liberal” Peacebuilding Debates', in Edward Newman, Roland Paris, and Oliver P. Richmond (eds), New Perspectives on Liberal Peacebuilding, Tokyo: United Nations University, 2009, pp.26-53; Paris (see n.23 above).

${ }^{27}$ Michael Pugh, 'Peacebuilding as Developmentalism: Concepts from Disaster Research’, Contemporary Security Policy, Vol.16, No.3, 1995, pp.320-346.

${ }^{28}$ Jefferson (see n.22 above).

${ }^{29}$ Ibid, p.254.

${ }^{30}$ Tomas Max Martin, 'Reasonable Caning and the Embrace of Human Rights in Ugandan Prisons', Focaal-Journal of Global and Historical Anthropology, No.68, 2014, pp.68-82, at p.70.

${ }^{31}$ Ibid; Tomas Max Martin, 'The Importation of Human Rights by Ugandan Prison Staff', Prison Service Journal, No.212, 2014, pp.45-51.

${ }^{32}$ Olivier de Sardan, 2011, p.25 as cited in Martin (see n.30 above), p.69.

${ }^{33}$ Martin, 'Reasonable Caning and the Embrace of Human Rights' (see n.30 above); Martin, 'The Importation of Human Rights' (see n.31 above).

${ }^{34}$ Martin (see n.30 above), p.79. 
This is an author-produced, peer-reviewed version of this article. The final, definitive version of this document can be found online at International Peacekeeping, published by Routledge. Copyright restrictions may apply. doi: 10.1080/13533312.2015.1041383

${ }^{35}$ Laura Piacentini, 'Prisons during Transition: Promoting a Common Penal Identity through International Norms', in Sarah Armstrong and Lesley McAra (eds), Perspectives on Punishment: The Contours of Control, New York:

Oxford University Press, 2006, pp.110-118.

${ }^{36}$ Ibid., p.113.

37 See ibid.

${ }^{38}$ Andy Aitchison, 'Global Meets Local: International Participation in Prison Reform and Restructuring in Bosnia and Herzegovina’, Criminology \& Criminal Justice, Vol.10, No.1, 2010, pp.77-94.

${ }^{39}$ Ibid.

${ }^{40}$ See ibid., p.88.

${ }^{41}$ Andrew M. Jefferson, 'Reforming Nigerian Prisons: Rehabilitating a 'Deviant' State', British Journal of

Criminology, Vol.45, No.4, 2005, pp.487-503; Jefferson, 'Prison Officer Training and Practice in Nigeria' (see n.22 above).

${ }^{42}$ Tomas Max Martin, Andrew M. Jefferson, and Mahuya Bandyopadhyay, 'Sensing Prison Climates: Governance, Survival, and Transition', Focaal-Journal of Global and Historical Anthropology, No.68, 2014, pp.3-17, at p.5.

${ }^{43}$ Jefferson (see n.22 above), p.265.

${ }^{44}$ Jefferson (see $\mathrm{n} .41$ above).

${ }^{45}$ Ibid., p.491.

46 Jefferson (see n.22 above).

${ }^{47}$ Martin et al. (see n.42 above), p.3.

${ }^{48}$ Ibid., pp.3,6.

${ }^{49}$ See ibid., p.6.

${ }^{50}$ Independent International Commission on Kosovo, The Kosovo Report: Conflict, International Response, Lessons Learned, New York: Oxford University Press, 2000.

${ }^{51}$ It is instructive to note the Western/non-Western dichotomy used throughout this paper is meant to illustrate the distinction between Western-European and North American democracies and nations with other forms of governance in place that are transitioning to democratic governance. At the conclusion of the NATO-led air campaign against the President of Yugoslavia and his troops in June 1999, UNMIK and NATO-led KFOR were established in the internationalized territory, with UNMIK taking over as a transitional administration, engaging in democratization and economic liberalization activities within Kosovo.

${ }^{52}$ Seth G. Jones, Jeremy M. Wilson, Andrew Rathmell, and K. Jack Riley, 'Establishing Law and Order after Conflict', [RAND Corporation Monograph Series,] Santa Monica, CA: RAND: Infrastructure, Safety, and Environment, 2005; Vivienne O’Connor, Colette Rausch, Hans-Joerg Albrecht, and Goran Klemencic, 'The Model Codes Project: A Response to Post-Conflict Criminal Law Needs', in Vivienne O’Connor, Colette Rausch, HansJoerg Albrecht, and Goran Klemencic (eds), Model Codes for Post-Conflict Criminal Justice: Volume I Model Criminal Code, Washington, DC: United States Institute of Peace Press, 2007, pp.3-9; Hansjörg Strohmeyer, 'Collapse and Reconstruction of a Judicial System: The United Nations Missions in Kosovo and East Timor', American Society of International Law, Vol.95, No.1, 2001, pp.46-63.

53 J. Tim Goddard, 'The Role of School Leaders in Establishing Democratic Principles in a Post-Conflict Society', Journal of Educational Administration, Vol.42, No.6, 2004, pp.685-696.

${ }^{54}$ United Nations Interim Administration Mission in Kosovo, 'Pillar I: Police and Justice, Presentation Paper: Third Quarter', United Nations Interim Administration Mission in Kosovo, July 2003 (at:

www.pfpk.wikispaces.com/file/view/Pillar+I+Report+July+2003.pdf).

${ }^{55}$ Department of Peacekeeping Operations (see n.16 above).

${ }^{56}$ Aitchison (see n.38 above).

${ }^{57}$ Bastick (see n.13 above).

58 Jefferson (see n.22 above), p.254.

${ }^{59}$ Martin et al. (see n.42 above), p.5.

60 Jefferson, 'Reforming Nigerian Prisons' (see n.41 above); Jefferson, 'Prison Officer Training and Practice in Nigeria' (see n.22 above); Martin, 'Reasonable Caning and the Embrace of Human Rights' (see n.30 above); Martin, 'The Importation of Human Rights' (see n.31 above); Martin et al. (see n.42 above); Piacentini (see n.35 above).

${ }^{61}$ United Nations Interim Administration Mission in Kosovo (see n.54 above).

${ }^{62}$ UN, 'Report of the Secretary General: Report on the United Nations Interim Administration in Kosovo', UN doc., S.779, 1999.

${ }^{63}$ United Nations Interim Administration Mission in Kosovo (see n.54 above). 
This is an author-produced, peer-reviewed version of this article. The final, definitive version of this document can be found online at International Peacekeeping, published by Routledge. Copyright restrictions may apply. doi: 10.1080/13533312.2015.1041383

${ }^{64}$ Gary Hill, ‘United Nations Helps Establish Kosovo Correctional Service’, American Correctional Association, Corrections Compendium, 01 May 2002 (at:

www.thefreelibrary.com/United+Nations+helps+establish+Kosovo+Correctional+Service....-a086683937); Strohmeyer (see n.52 above); United Nations Interim Administration Mission in Kosovo, 'Pillar I: Police and Justice, Presentation Paper’, United Nations Interim Administration Mission in Kosovo, Jun. 2004, (at: www.pfpk.wikispaces.com/file/view/PillarI+Report+June+2004.pdf).

${ }^{65}$ Strohmeyer (see n.52 above); UN (see n.62 above).

${ }^{66}$ Strohmeyer (see $\mathrm{n} .52$ above).

${ }^{67}$ Ibid.

${ }^{68}$ Ibid.; United Nations Interim Administration Mission in Kosovo (see n.64 above).

${ }^{69}$ Human Rights Watch, 'Failure to Protect: Anti-Minority Violence in Kosovo, March 2004', Human Rights Watch, Vol.16, No.6D, Jul. 2004, (at: www.hrw.org/sites/default/files/reports/kosovo0704.pdf); Ray Murphy, UN Peacekeeping in Lebanon, Somalia and Kosovo: Operational and Legal Issues in Practice, Cambridge, UK: Cambridge University Press, 2007.

${ }^{70}$ Bastick (see $n .13$ above).

${ }^{71}$ Bruce Baker, 'The African Post-Conflict Policing Agenda in Sierra Leone', Conflict, Security \& Development, Vol.6, No.1, 2006, pp.25-49; Timothy Donais, 'Peacekeeping's Poor Cousin: Canada and the Challenge of PostConflict Policing’, International Journal, Vol.59, No.4, 2004, pp.943-963.

${ }^{72}$ Donais (see $n .71$ above).

${ }^{73}$ It is important to acknowledge the opinions and conclusions presented in this article do not necessarily represent those of the Correctional Service of Canada.

${ }^{74}$ Correctional Service of Canada, 'Peace-Building and Reconstruction Missions: Kosovo', Correctional Service of Canada, 05 Jun. 2009 (at: www.cscscc.gc.ca/text/intlforum/pbrm/kosovoeng.shtml).

${ }^{75}$ Bill Rankin, 'CSC in Kosovo', Let’s Talk, Vol.27, No.2, 2002, pp.2-11.

${ }^{76}$ The Simon Fraser University Research Ethics Board granted me permission to conduct all of the interviews without written informed consent, as I proposed obtaining oral consent to decrease potential concerns about anonymity/confidentiality. The CSC Research Branch requested that I obtain written consent forms; therefore, written consent was obtained from current CSC employees who went to Kosovo as gratis staff.

${ }^{77}$ Note that on one occasion, every question on the interview schedule was not asked, as this interview was timerestricted. I chose to sacrifice asking all of the questions in exchange for receiving rich descriptions for the questions the participant indicated s/he could really elaborate on given her/his experiences.

${ }^{78}$ Martin et al. (see n.42 above), p.5.

${ }^{79}$ Ibid., p.6.

${ }^{80}$ See ibid., p.6.

${ }^{81}$ Jefferson (see $\mathrm{n} .41$ above).

82 Jefferson (see n.22 above), p.266.

${ }^{83}$ Jefferson, 'Reforming Nigerian Prisons' (see n.41 above); Jefferson, 'Prison Officer Training and Practice in Nigeria' (see n.22 above); Martin, 'Reasonable Caning and the Embrace of Human Rights' (see n.30 above); Martin, 'The Importation of Human Rights' (see n.31 above); Martin et al. (see n.42 above); Piacentini (see n.35 above).

${ }^{84}$ Mark Shaw, 'Interim Justice and Security Arrangements in States Transitioning from Authoritarian to Democratic Rule', International Network to Promote the Rule of Law, July 2012 (at: www.statt.net/wp-content/uploads/2012/08/RM-Security-Arrangements-in-the-Transition.pdf).

${ }^{85}$ Baker (see n.71 above); Rod Broadhurst and Thierry Bouhours, 'Policing in Cambodia: Legitimacy in the Making?’, Policing and Society, Vol.19, No.2, 2009, pp.174-190.

${ }^{86}$ Phillipe Le Billon, 'Corrupting Peace? Peacebuilding and Post-Conflict Corruption', International Peacekeeping, Vol.15, No.3, 2008, pp.344-361.

${ }^{87}$ United States Department of State, 'Country Reports on Human Rights Practices for 2011: Kosovo, 2011', United States Department of State, 2011 (at: www.state.gov/documents/organization/186578.pdf).

${ }^{88}$ Organization for Economic Co-operation and Development (OECD), 'Perspectives Note: The Enabling Environment for Capacity Development', OECD, Jan. 2011 (at: www.oecd.org/development/governancedevelopment/48315248.pdf); United Nations Development Programme, 'Capacity Development: Practice Note', New York: United Nations Development Programme, 2008.

${ }^{89}$ United Nations Office of Drugs and Crime (see n.20 above). 
${ }^{90}$ International Corrections and Prisons Association, 'Practical Guidelines for the Establishment of Correctional Services within United Nations Peace Operations’, International Corrections and Prisons Association, 2002 (at: www.icpa.ca/tools/download/448/ICPA_Practical_Guidelines.pdf).

${ }^{91}$ Office of the United Nations High Commissioner for Human Rights (see n.10 above).

92 Goddard (see n.53 above).

93 Strohmeyer (see n.52 above).

94 Baker (see n.71 above); Donais (see n.71 above).

${ }^{95}$ Bastick (see n.13 above).

96 Yvon Dandurand, Curt T. Griffiths, and Vivienne Chin, 'Training and Effective Support of Comprehensive Justice and Security Reforms: Outcomes to Date and Lessons Learned’, in Kauko Aromaa, and Slawomir Redo (eds), For the Rule of Law: Criminal Justice Teaching and Training across the World, Helisnki: European Institute for Crime Prevention and Control, 2008, pp.53-67; Donais (see n.71 above).

97 Jefferson, 'Reforming Nigerian Prisons'(see n.41 above); Jefferson, 'Prison Officer Training and Practice in Nigeria’ (see n.22 above); Martin, ‘Reasonable Caning and the Embrace of Human Rights’ (see n.30 above); Martin, 'The Importation of Human Rights’ (see n.31 above); Piacentini (see n.35 above); Pouligny (see n.7 above).

${ }^{98}$ Piacentini (see n.35 above).

${ }^{99}$ Alex J. Bellamy and Paul Williams, Understanding Peacekeeping, (2nd edn), Cambridge, UK: Polity Press, 2010.

${ }^{100}$ Oliver P. Richmond, 'UN Peace Operations and the Dilemmas of the Peacebuilding Consensus', International Peacekeeping, Vol.11, No.1, 2004, pp.83-101.

${ }^{101}$ UN Secretary General (see n.8 above).

102 Martin et al. (see n.42 above), p.6.

103 Sulkan Barakat, 'The Failed Promise of Multi-Donor Trust Funds: Aid Financing as an Impediment to Effective State-Building in Post-Conflict Contexts’, Policy Studies, Vol.30, No.2, 2009, pp.107-126; Curt T. Griffiths, 'Implementing International Standards in Corrections: Challenges, Strategies, and Outcomes', The United Nations Office on Drugs and Crime Expert Group Meeting: The Application of United Nations Standards and Norms in Crime Prevention and Criminal Justice, Burgenland, 10-12 Feb. 2003 (at:

www.curtgriffiths.com/pdfs/Vienna\%20corrections.pdf); Curt T. Griffiths, Yvon Dandurand, and Vivienne Chin, 'Development Assistance and Police Reform: Programming Opportunities and Lessons Learned', The Canadian Review of Policing Research, Vol.2, No.1, 2005, pp.101-113.

${ }^{104}$ United Nations Development Programme (see n.88 above). 